\title{
At the Margin of Educational Policy: Sámi/Indigenous Peoples in the Swedish National Curriculum 2011
}

\author{
Charlotta Svonni \\ Department of Historical, Philosophical and Religious Studies, Vaartoe/Centre for Sami Research, \\ Umeå University, Umeå, Sweden \\ Email: charlotta.svonni@umu.se
}

Received 5 March 2015; accepted 9 June 2015; published 12 June 2015

Copyright (C 2015 by author and Scientific Research Publishing Inc.

This work is licensed under the Creative Commons Attribution International License (CC BY).

http://creativecommons.org/licenses/by/4.0/

(c) (i) Open Access

\begin{abstract}
According to international and national legislation, the Sámi people in Sweden have the right to self-determination; more specifically, they have the right to form their own education. Current compulsory education is guided by the national curricula, Lpo 11. Thus, the curricula heavily influence education in schools throughout the country. In this paper, a content analysis is performed to explore the Lpo 11 from an Indigenous perspective, and it scrutinizes if and how Sámi culture, values, traditions and knowledge are salient in the curricula. The results show that the Sámi thematic only has a minor place in the Lpo 11. In relation to expectations in international conventions and national legislation addressing Indigenous peoples and national minorities, there is a need of a higher degree of the Sámi thematic in the curriculum.
\end{abstract}

\section{Keywords}

Curricula, Education, Indigenous Peoples, Sámi People

\section{Introduction}

The Sámi people were officially recognized as an Indigenous people by the Swedish government in 1977. The land of the Sámi, Sápmi, stretches across four countries: Finland, Norway, Russia and Sweden. There are officially approximately 20,000 Sámi in Sweden, and they have been recognized as a national minority since 2000 (SFS 2009:724, SÖ 2000:2). Since 2010, the Sámi people have also been recognized as a people in the Swedish constitution and, as such, have the same right to self-determination as the Swedes (Regeringsformen, 1 chapter, $2 \S)$. Indigenous peoples, such as the Sámi, have been subjected to historical injustice and discrimination with contemporary implications such as loss of vast landholdings and the suppression of political and cultural institu- 
tions. This has led to a weakening of the Indigenous peoples' economy and culture as well as an undermining of their cultural integrity (Anaya, 2004: p. 4; Pikkarainen \& Brodin, 2008). There are also prejudices against the Sámi (Pikkarainen \& Brodin, 2008), who often feel a need to suppress their ethnicity and adjust to the majority society in order to become accepted (Blind, 2006). The Sámi identity is a complex issue both on an individual and a group level (Amft, 2000: p. 171), and it is defined differently according to how and where one is raised (Åhren, 2008: p. 171). There are different ethnicity markers, and they can be changeable over time. These attributes can be: language, clothing, reindeers and everything connected to the reindeer, duodji (Sámi handicraft), food, participation in Sámi social context, and inclusion in the electoral register of the Sámi Parliament (Amft, 2000: pp. 181-182). A place and an area in nature are strong identity pillars for many Sámi people on both an individual and a collective level. The role of a place is important in many aspects; it describes a history, contemporary time and the future. The strong relationship between a person and a geographic area in which they feel connected to is described as something physical and embodied. It includes many holy places and a long history of invisible knowledge and values (Cocq, 2014: p. 8). There is a prominent lack of knowledge about the Sámi, in general, and educational material, such as textbooks, generalize and contain negative descriptions which lead to stereotypic misconceptions (Pikkarainen \& Brodin, 2008).

There is a strong correlation between knowledge and social identity, and education is one of the most important institutions for socializing and thus leading to presumptions on what society is and to what it should evolve (Ledman, 2015: p. 2). The Swedish curriculum articulates that the role of education and upbringing in essence is "to transfer and develop a cultural heritage—values, traditions, language, knowledge-from one generation to the next" and that "schools should impart the more resistant skills that constitute the common frame of reference all in societal need." (Lpo 11, National Compulsory School Curricula 2011). This implies that education is important for Sámi as well as for Swedish children's ability to develop their identity, culture and knowledge. However, education has not only been an institution of knowledge, it has also reproduced and preserved differences among ethnicities (Tallberg, Rubenstein, \& Hägerstöm, 2002: p. 105). To achieve knowledge there is a need to control education through the curriculum (Merey, 2012). The curriculum is an important steering document, which "makes space like nothing else (...) in education." It may also constitute "a mighty tool of social justice for the marginalized" (Kovach, 2009: p. 6).

There are only five Sámi schools situated in the northwest parts of Sweden (Sameskolstyrelsen) and because of that most of the Sámi students attend the compulsory schools and get educated according to that curriculum. Hence, the Lpo 11 is an important document that should enable the Sámi to exercise their right to decide over their own education, as part of their right to self-determination. This document is also obliged to guide teachers to provide a correct picture of the Sámi people, their history and culture to avoid further discrimination and stereotypic misconceptions and to make the content about the Sámi people from the Sámi perspective.

What this means in practice and to what extent the Sámi thematic is implemented in Swedish educational policy and practice has, however, not been subject to critical analysis. The aim of this study is thus to evaluate how and to what extent the Sámi thematic is present in the Swedish compulsory national curriculum and mandatory syllabiin relation to international and national legislation.

\section{Human and International Rights}

Indigenous peoples work in transnational organizations to get their rights recognized (Anaya, 2004: p. 8). Human rights and its implications have led to a normative framework, which has increased legitimacy to Indigenous peoples' claim of recognizable rights (Miranda, 2013; Abate \& Kronk, 2013). The normative core values addressing Indigenous peoples' self-determination are related to human rights and are built on existing written documents and interpretations of authorized institutions and consensus building among states, Indigenous peoples and other actors. These core values are categorized in: non-discrimination, cultural integrity, lands and natural resources, social welfare and development and self-government (Anaya, 2004: pp. 8-9). The following gives a background of what expectations there are on education in accordance to Indigenous peoples and national minorities in Sweden.

\subsection{Rights as a People}

The International Covenant on Civil and Political Rights states the rights a people have. Since the Sámi people have status as a people according to the Constitution of Sweden, it means that the Sámi people have right to self-determination and have the right to determine their political status and also determine and develop their economy, society and culture (Article 1). Self-determination requires both autonomy for Indigenous institutions 
and a higher political mandate for Indigenous participation (Anaya, 2004: p. 9). The Indigenous and Tribal Peoples Convention, ILO 169, states what rights Indigenous peoples have, which includes the rights of Indigenous children in matters of education. This convention has not been ratified by Sweden, however, and will not be considered in this article.

\subsection{Rights as a Minority}

According to the Council of Europe's framework Convention for the Protection of National Minorities: "The Parties shall, where appropriate, take measures in the fields of education and research to foster knowledge of the culture, history, language and religion of their national minorities and of the majority.” (Article 12:1). The Parties shall also provide for teacher training and access to textbooks in this context and minorities' language and culture are to be protected from assimilation (Framework Convention for the Protection of National Minorities, Article 5, 12: p. 2). According to Swedish legislation the Sámi as a national minority, has the right to learn, evolve and use their language. In addition, the use of their minority language should be protected and promoted particularly. The public has also a responsibility to encourage the Sámi people to preserve and develop their culture, and a child has the right to develop a cultural identity (SFS 2009:600, SFS 2009:724).

\subsection{Rights as an Indigenous Child}

The Convention on the Rights of the Child (CRC) aims to protect and provide for directions so children can develop emotionally, economically, healthily, independently, mentally, morally, physically and socially (Merey, 2012). Sweden has ratified the CRC in 1990 without any reservations (Prop. 1989/90: p. 107). There are four fundamental needs identified in the CRC: the right to life, development, protection and participation. The right to life means the right to a sufficient standard of living, not to be discriminated by family, school and society. It also includes medical care, nutrition and somewhere to live. The right to development includes education, play, rest, religion and freedom of opinions and conscience. Protections refer to safety against abuse and exploitation. The right to participation includes the right to participate in a family and society, to be able to express opinions and make choices that will affect them. It also includes peaceful assemblies and creates relations (Merey, 2012). The parts considered in the CRC in this study are the ones connected to expectations on education addressing ethnicity and Indigenous peoples. It says: "Education should aim to develop respect for the child's own cultural identity, language and values.” (Article 29.1.c). Indigenous peoples' children also have the right to enjoy their own culture, and are allowed to practice their own religion and use their own language (Article 30).

\subsection{Rights as a Sámi}

These conventions and legislation mean that the Sámi, since they are a people, have the right to self-determination and therefore the right to decide over their education and have a mandate to influence the education system. Since they are a national minority, they have the right to education about Sámi knowledge of culture, history, language and religion, where it is appropriate. As a national minority they are also to be protected from assimilation. Like other children, Sámi children have the right to not be discriminated against in school and society, as well as the right to development in education, opinions and conscience. They have also the right to participation in family and society and to be able to express opinions and make choices that affect them. There is no national legislation that explicitly addresses the Sámi as an Indigenous people, but the national legislation that addresses national minorities applies to the Sámi people since they are recognized as a national minority, which means to preserve and develop their culture and their cultural identity.

\subsection{The Swedish School System and the National Curriculum}

The compulsory school education attendance starts when the child reaches the age of seven and is divided into nine classes. There is a national curriculum for all compulsory schools, and it is divided into three parts: 1) the schools' values and assignment, 2) the general goals and guidelines and 3) the syllabi for all the school subjects. The syllabus is further divided into three parts: the aims, central contents and knowledge requirements guiding the grades. There are municipal as well as private schools in the country, and there are alternatives such as the Sámi schools. Today all Sámi have the right to choose their educational system (Parliamentary resolution 1962 regarding the Nomadic School), but until 1962 the Sami connected to the mountain reindeer husbandry had to attend the 
Sámi school, while other Sámi had to attend Swedish schools (SFS 1938:479). The Sámi compulsory school provides education from year one to six, and is run by the government (SFS 2010:800, Lpo 2011, Lpo for the Sámi School 2011). The Sámi school emphases Sámi culture and language and implements the Sámi thematic in all school subjects (Sameskolstyrelsen). The Sámi school has a national curriculum that is almost identical to the compulsory Lpo 11, the difference is the syllabus for the Sámi language (Lpo 11 for the Sámi school). This syllabus is not included in this study since it not is a mandatory syllabus for all students in Sweden. Another syllabus that gives the Sámi students an opportunity to learn the Sámi language is mother tongue. This subject and other not mandatory syllabi for all students in Sweden are not considered further in this article.

\subsection{Participation of Indigenous People in Education}

The desire to learn is one of the cornerstones in education, and teachers shall consider every student's needs, experiences and knowledge (Lpo, 2011). It is shown that contextualization engages students in their education because it helps them to relate to the subject: but for Indigenous peoples, the education doesn't connect to their own cultural knowledge and little has been improved to accommodate their alternative experiences in the educational structure (Rahman, 2013). Within the Sámi community the expression Àrbediehtu is their own traditionally born knowledge and their own experiences of the environment and its effects on their living condition. This is transferred from one generation to the next (Utsi, 2007: p. 61). The gain for the Indigenous people with an interaction with their own culture in school is that education will make sense and be in harmony with their own cultural knowledge. In Aotearoa/New Zealand, a power imbalance is made through colonial domination. With an offering of an alternative approach in the mainstream classroom all students would benefit from Māori experiences of colonization and resistance to get better relationships. Bishop means that the lack of knowledge and theories of cultural deficit blames the ones with problems, and they are the ones who need to change instead of admitting the inherited power imbalance from colonization (Bishop, 2003: pp. 222-223).

In Sweden there is no study about power imbalance or studies that compare educational achievement between Sámi and Swedes; however, there is a study that shows that Sámi school children have lower health-related quality of life (HRQL) than Swedish children. The education situation was one of the areas where they scored lower than the Swedes. The children who were badly treated because of their Sámi heritage were reported to have a lower HRQL (Omma, 2013: p. 33). If there was a better understanding of the Indigenous children in school and the power imbalance would be recognized, the Indigenous culture would be able to open up to the majority society because they will have a secure cultural framework (May, 1996b in Bishop, 224). In other Indigenous contexts there are experiences to learn from. An example from New Zealand and Māori theory shows that progress is possible if Indigenous peoples not only start to question the division between colonizer and themselves, but also strive to find ways of eliminating it (Rico, 2013). Inclusiveness would reduce barriers for education for all students and would diminish the risk of marginalization, exclusion or underachievement (Ainscow, 2004). In Nigeria, Rasheed (2014) argues for inclusiveness for all students in the regular schools to remove discrimination and accomplish a free and democratic society. Rasheed means that stereotypical beliefs about students in special schools would diminish if all students went to the regular school (Rasheed, 2014). I agree with Rico and Ainscow in the importance of a secure framework for Indigenous peoples to be able to open up to the majority and for the Indigenous peoples to find ways to eliminate the division between the colonizer and themselves. This is a two-way street: The colonizer also has to be open to the Indigenous way of thinking and knowing. Rasheed's suggestion of inclusiveness for all students in regular school is one way. I agree that all students should have the right to choose and be welcome in the regular school, but there should also be special schooling for those who want that possibility.

The classroom should be a place where students can make sense of what they learn and with models that incorporate Indigenous knowledge as Bishop suggests. It can generate a better understanding for both Sámi and Swedish and other cultures. In a multicultural world, the teachers have to take in knowledge from different cultures and make sense of it and pass it on to the students (Bishop, 2003). Globalization and intercultural relations are a fact in the world today and have been recognized in the curricula and education (Kalantzis and Cope, 2012). The curriculum lifts the importance of the cultural values in the context of international perspective. It verbalizes that the international perspective is to evolve understanding of cultural variety within the country. Another part where culture lifts in Lpo 11 is in the meaning of common cultural heritage. The students are to be conscious about their own and the common cultural heritage to become confident in their identity and to understand other peoples' life situations and values. This is to have knowledge and be able to work together with other people and have an 
understanding of their culture, language, religion and history (Lpo, 11). On the other hand, the school values articulate that all people have equal value in accordance with the ethics managed in Christian tradition and Western humanism. These values are then explained as generosity, tolerance, responsibility and a sense of justice (Lpo 11).

\section{Theory and Method}

To identify to what extent the Sámi thematic is included in the Swedish compulsory education, a content analysis of the Swedish national curriculum, Lpo 11, was performed. The entire document, including the syllabi for the 16 mandatory subjects, was scanned for Sámi-, Indigenous- and minority thematic. These three search terms were chosen as the Sámi people are recognized as a people, indigenous people and a national minority in Sweden. The sentences where the Sámi peoples were explicitly mentioned were subjected to further analysis and, when relevant, assessed according to the six levels in the cognitive domain of Bloom's taxonomy (Bloom, 1956). These are, from the lowest order processes to the highest: knowledge, comprehension, application, analysis, synthesis and evaluation.

The findings of the Sámi thematic in the Lpo 11 were thereafter discussed from a postcolonial Indigenous perspective to recognize the colonial impact on the educational steering document. This perspective means that a superior tries to bring evolvement to Indigenous peoples and has a great impact on the Indigenous way of living, knowing and their social and spiritual ways so it will be like the Western way to be (Smith, 2012: p. 58). Colonization is not only about taking over lands; it is also about taking over a people's knowledge system (Kovach, 2009). The viewpoint in the discussion is that Sweden colonized Sápmi and the people of Sápmi. The education system, through the written curricula, is one area where colonization of Sámi knowledge continues. In the discussion both international and national documents are considered to highlight possible tensions between expectations on education from international conventions and national legislation that address Indigenous peoples in comparison to the Lpo 11.

\section{Results}

The results are reported according to the structure of the curriculum, which is in total 279 pages, including all syllabi. First, the school values and assignment were assessed and thereafter the general goals and guidelines, which state the norms, values and knowledge that all students should have achieved during their compulsory schooling and provides the direction for the schoolwork. The third part assessed were the syllabi for all the school subjects. The syllabi are further divided into three parts: general goals and guidelines, central contents and knowledge requirements/grades. The word Indigenous is only mentioned in the same sentences as the word Sámi and therefore only the words Sámi and minority will be presented in the results. For a summary of the results, see Table 1.

\subsection{School Values and Assignment}

Neither Sámi nor minorities are mentioned in this part, which is four and a half pages long.

\subsection{General Goal and Guidelines}

The general goal and guidelines of the curricula provide the direction of the schoolwork and is eight pages long. This part is divided into eight subtitles, one of them being general knowledge. There are 16 requirements of knowledge and one of them with a Sámi thematic, "each student completing the school (...) have gotten knowledge about the national minorities (Jews, Romanize, the Indigenous people Sámi’s, Sweden Finish's, and Tornedalingars) culture, language, religion and history.” To have knowledge of a subject is the lowest level in the cognitive domain according to Bloom’s taxonomy (Bloom 1956).

\subsection{Syllabi}

The curriculum contains 16 syllabi, that is, 16 subjects that all students have to learn. In these syllabi, there is a total of 804 central contents provided, covering all subjects from year one to nine. The Sámi are mentioned four times in the syllabi, which corresponds to $0.5 \%$ of all central contents. The central contents where Sámi thematic is found cover historical perspectives on their situation in Sweden (history syllabus, central content, grade 7 - 9) as well as their rights today; and their unique position as an Indigenous people of Sweden and what that means (social science syllabus, central content, grade 4 - 6 and 7 - 9). Also the stories from old Sámi religion should be known about (religion syllabus, central content, grade 4 - 6). 
Table 1 . Summary of results.

\begin{tabular}{|c|c|c|c|}
\hline Section & Sub section & Topic & Formulation ( ${ }^{*}$ original text in Swedish) \\
\hline $\begin{array}{l}\text { General goals } \\
\text { and } \\
\text { guidelines }\end{array}$ & Knowledge and goals & & $\begin{array}{l}\text { It shall be the schools responsibility that all pupils completing } \\
\text { primary school ... "has got knowledge of the national minorities } \\
\text { (Jews, Roma, indigenous Sámi people, Sweden Finns and } \\
\text { Tornedalers) culture, language, religion and history” } \\
\text { *Skolan ska ansvara för att varje elev efter genomgången } \\
\text { grundskola...” har fått kunskaper om de nationella minoriteternas } \\
\text { (judar, romer, urfolket samerna, sverigefinnar och tornedalingar) } \\
\text { kultur, språk, religion och historia” }\end{array}$ \\
\hline Syllabus & $\begin{array}{l}\text { History, central content, } \\
\text { grades } 7 \text { - } 9\end{array}$ & $\begin{array}{l}\text { Democratization, post-war } \\
\text { and globalization, about } 1900 \\
\text { to the present }\end{array}$ & $\begin{array}{l}\text { Historical perspective on the indigenous Sami and other national } \\
\text { minorities' situation in Sweden } \\
\text { *Historiska perspektiv på urfolket samernas och de övriga nationella } \\
\text { minoriteternas situation i Sverige }\end{array}$ \\
\hline Syllabus & $\begin{array}{l}\text { Social sciences, central } \\
\text { content, grades } 4 \text { - } 6\end{array}$ & Individuals and communities & $\begin{array}{l}\text { Indigenous Sami people and other national minorities in Sweden. } \\
\text { The rights of the national minorities. } \\
{ }^{*} \text { Urfolket samerna och övriga nationell minoriteter i Sverige. De } \\
\text { nationella minoriteternas rättigheter. }\end{array}$ \\
\hline Syllabus & $\begin{array}{l}\text { Social sciences, central } \\
\text { content, grades } 7 \text { - } 9\end{array}$ & Rights and justice & $\begin{array}{l}\text { The national minorities and the status of the Sami's as an Indigenous } \\
\text { people in Sweden, and what their special status and rights means } \\
{ }^{*} \text { De nationella minoriteterna och samernas ställning som urfolk i } \\
\text { Sverige samt vad deras särställning och rättigheter innebär }\end{array}$ \\
\hline Syllabus & $\begin{array}{l}\text { Religion, central } \\
\text { content, grades } 4 \text { - } 6\end{array}$ & $\begin{array}{l}\text { Religion and other philosophies } \\
\text { of lives }\end{array}$ & $\begin{array}{l}\text { Stories from ancient Scandinavian and old } \\
\text { Sámi religion } \\
{ }^{*} \text { Berättelser från fornskandinavisk och äldre samisk religion }\end{array}$ \\
\hline
\end{tabular}

\subsection{Knowledge Requirements/Grades}

The word Sámi only occurs in the knowledge requirements in the Religion syllabus, but it does not require any evolvement in the grading levels. It is the same requirement in the grade of E, C and A in the end of year six, which is: "The student can describe some basic features of the ancient Scandinavian and Sámi religion and also provides examples of how the ancient Scandinavian religion can be observed in today's society.” (Lpo 11). In history and social sciences, where the Sámi thematic is included in the central content, there is lack of knowledge requirements addressing the Sámi thematic.

\section{Discussion}

\subsection{Does the Curriculum Live up to Human Rights and Legislation?}

According to the Covenant of Civil and Political Rights and the Swedish Constitution, the Sámi have the right to be included in the national curricula, since they are a people in Sweden. When considering legislation like; Convention on the Rights of the Child, the Covenant on Civil and Political Rights, Constitution of Sweden, The Language Act and the Act on National Minorities and Minority language, it is clear the Sámi people's knowledge, history and culture has to be given a greater part in education and changes should be introduced to the curricula in order for the document to live up to international and national expectations on education addressing Indigenous peoples.

\subsection{Educational Rights as a People}

As a people, the Sámi has the right to form their own education. Since there are only five Sámi schools and most of the Sámi attend the Swedish compulsory school, the Sámi should be able to have an impact on the curriculum and mandatory syllabi. This would be possible since there are political structures provided through the popularly elected Sámi Parliament, which should be mandatory, involved in the formulation of curricula. The current compulsory school curriculum is adapted to a wish of what Swedes should be, since the curriculum lays down 
conditions for equal value to Christian tradition and Western humanism. From a Sámi Indigenous perspective the written curriculum directs the interpretation that generosity, tolerance, responsibility and sense of justice are values of those assigned to themselves to the heritage of the world of Christian traditions and the Western world. Formulations like Christian ethics and Western humanism should be excluded, since it gives the impression that these are the only cultural ethics and norms worth having. It also implies that other possible interpretations of generosity, tolerance, responsibility and sense of justice are not as relevant in Sweden. If the interpretation of transfer and development is connected to every child's cultural heritage, then this is in accordance with the convention's expectations on education. However, with a prelude of values of Christian tradition and Western humanism, all other ethnicities that are different from Christianity and the West are excluded. It is an indication that Swedish is the frame for values; therefore it is a specific form of Swedish traditions, language and knowledge that are to be transferred to the next generation. It would supposedly mean that it is the Swedish skills and common frame that is the reference to what society needs. The curriculum includes different peoples, minorities and different cultures, but the contextualization of values guides the interpretation of Lpo 11 to only consider and educate according to the Swedish language, culture and values, with trivial consideration of the Sámi people's language, culture and values. In this sense and based on the fact that the Sámi have limited possibilities to influence the curricula, the Lpo 11 doesn't live up to the Covenant of Political and Civil Rights and elucidate a structure of power imbalance between the Swedish and the Sámi people.

\subsection{Educational Right as a Minority}

As a minority, the students should throughout their education acquire knowledge about their own culture, history, language and religion - and should not be subjected to forced assimilation. They should also be allowed to develop their cultural identity and to learn, evolve and use their language. The syllabi in Lpo 11 that explicitly address minorities are history, social science and Swedish language. The low degree of visibility and knowledge requirements of minority topics can't possibly live up to the expectations of providing and evolving their cultural identity, learning and evolving their language, nor getting knowledge about their culture, history and religion. The schools' values articulate respect and tolerance for other peoples, but it also guides into Swedish norms and values, which means it is an area where minorities do get assimilated into the Swedish society.

\subsection{Educational Right as a Child}

There are little openings in the Lpo 11, to live up to international conventions and national legislation concerning Indigenous children of Sweden. The Sámi thematic is only included in four out of 804 central contents in the syllabi. In addition, they are only mentionedin the knowledge requirements in the religion syllabus where it only requires the lowest cognitive domain according to Blooms taxonomy (Bloom, 1956). In all other syllabi there is lack of knowledge requirements, which means there is no obligation of evaluation the students' knowledge about Sámi themes even where the Sámi thematic is included as central content. There is also a lack of directed requirements of developing Sámi cultural identity, language and values and a lack of a formulation of tolerance of persons of Indigenous origin, which is articulated in CRC (Article 29 a-c). When Sámi themes only make out $0.5 \%$ of the syllabi contents (of what is to be learned), it doesn't leave much room for learning tolerance for the Sámi. This low degree of Sámi thematic and knowledge requirements can’t be regarded as the school provides for a progress opportunity for the Sámi children's own cultural identity, language and values as expected on education in the Convention on the Rights of the Child, it is rather an indication of marginalization of the Sámi people and their knowledge. The general goals and guidelines for the compulsory school require knowledge about the Sámi culture, history, religion and language. To have knowledge is, however, the lowest cognitive domain required in education according to Bloom's taxonomy. Surely the curricula articulate that "no one is to be discriminated because of their ethnicity" and "the school has to work to counteract discrimination and intolerance with knowledge and discussions and active work" (Lpo 11). Nonetheless, to develop the cultural identity, to learn tolerance for Indigenous individuals, when there already are prejudice and discrimination against the Sámi people, demands more than general work against discrimination. If the Lpo 11 lives up to the CRC's expectations on education is a question of interpretation. If the normative values figure there only is a need of knowing about the Sámi people, the Lpo 11 lives up to the CRC. However, if the intention is to have comprehension or to be able to analyze, make synthesis and evaluate the whole picture of the Sámi peoples' culture and knowledge and to be able to really understand the Sámi's life situation, then the Lpo 11 doesn't live up to the CRC, since the Sámi people's own cultural identity gets so little attention in the curriculum. 


\subsection{Benefits of Indigenous Impact on the Curricula}

Inclusiveness of Sámi knowledge and thematic within the compulsory school system is a way to diminish contradictions between the curricula and the Human Rights and national legislation, and also to increase awareness of different cultures. This will in the long run increase the awareness of globalization and intercultural question and problematic, which is one of the goals within the curriculum. It would also be beneficial for all students to get education in the Sámi thematic to gain a better understanding for the Indigenous peoples to diminish prejudice and the Sámi students would gain better understanding of the education with a Sámi contextualization. Including Àrbediehtu, the traditional knowledge, in the curricula is one possible way to accomplish intercultural education in Sweden. To define traditional knowledge the Convention on Biological Diversity can be used since it is a document which underlines respect, preservation and maintenance of Indigenous knowledge and their traditional lifestyle (Convention on Biological Diversity, Article 8j). However, from a Sámi perspective, the Convention is limited since it only considers biological diversity and ecological sustainable development. Àrbediehtu has a wider meaning, it: "clarifies knowledge as both information and the process, emphasizes different ways to gain, achieve or acquire knowledge. The concept indicates indissoluble ties between the past, the present and the future" (Porsanger, 2010: p. 435). The environmental sustainability can thus be seen as possibilities of lifting in Àrbediehtu in the curricula to better understand and respect nature.

\section{Conclusion}

This study has defined tensions between international conventions and steering documents for compulsory school education as well as formulations in the curricula's general goals and guidelines and Indigenous peoples' rights. There is a lack of the Sámi peoples' thematic in the syllabi and no evaluable knowledge goals in the knowledge requirements addressing the Sámi people's culture, history and living condition. There is however knowledge requirements of what are addressed as the old stories of Sámi religion in the syllabus of religion. In addition, the Sámi people are without a real influence of the compulsory curriculum, Lpo 11. This indicates a marginalization of the Sámi people and their knowledge as well as a power imbalance between the peoples of Sweden.

A policy reform is needed to sanction the Sámi peoples' influence over education and to customize the curricula to both the Swedish and the Indigenous people of Sweden. To lift Sámi knowledge and culture within Swedish education is not only beneficial to the Indigenous people, it is equally beneficial and evolving for all Swedes. The knowledge and experiences achieved by understanding different peoples is advantageous in a broader perspective for understanding all cultures and peoples within a country and among countries.

There is obviously a potential for important and necessary changes in the curriculum at several different levels that should be taken into account in the future. This implies that the authors of the curriculum not only should have a good understanding of both international and national laws regarding minorities and indigenous peoples, and how these rights can be supported through education, but also in Sami history, culture and the contemporary related situation.

\section{Acknowledgements}

The author wishes to thank Åsa Holmner for her generous support during the writing process.

\section{References}

(1989). Indigenous and Tribal Peoples Convention, No. 169. http://www.ohchr.org

Åhren, C. (2008). Är jag en riktig same? En etnologisk studie av unga samers identitetsarbete. Ph.D. Thesis, Umeå: Umeå University.

Amft, A. (2000). Sápmi I förändringens tid. En studie av svenska samers levnadsvillkor under 1900-talet ur ett genusoch etnicitetsperspektiv. Ph.D. Thesis, Umeå: Umeå University.

Anaya, S. J. (2004). Indigenous Peoples in International Law (2nd ed.). Oxford: Oxford University Press.

Bishop, R. (2003). Changing Power Relations in Education: Kaupapa Māori Messages for Main Stream Éducation in Aotearoa/New Zealand. Comparative Education, 39, 221-238. http://dx.doi.org/10.1080/03050060302555

Blind, E. (2006). Att förlora sitt språk. Att återta mitt språk. Åtgärder för att stärka det samiska språket. SOU, 19, Slutbetänkande från utredningen om finska och sydsamiska språken. 
Bloom, B. (1956). Taxonomy of Educational Objectives: The Classification of Educational Goals. Handbbok 1, Cognitive domain. New York: David McKay.

Cocq, C. (2014). Platsskapande och synliggörande in Kulturella perspektiv, Svensk etnologisk tidskrift. Umeå: Umeå Universitet, 5-12.

Convention on Biological Diversity. http://www.cbd.int

Convention on the Rights of the Child. http://www.ohchr.org

Framework Convention for the Protection of National Minorities. Council of Europe. http://www.conventions.coe.int

International Covenant on Civil and Political Rights. http://www.ohchr.org

Kalantzis, M., \& Cope, B. (2012). New Learning: A Charter for Change in Education. Critical Studies in Education, 53, 8394. http://dx.doi.org/10.1080/17508487.2012.635669

Kovach, M. (2009). Indigenous Methodologies. Characteristics, Conversations, and Context. Toronto: University of Toronto Press Inc.

Ledman, K. (2015). Historia för yrkesprogrammen. Innehåll och betydelse i policy och praktik. Ph.D. Thesis, Umeå: Umeå University.

Lpo 11 (2011). Läroplan för grundskolan, förskoleklassen och fritidshemmet 2011, Skolverket, Stockholm. http://www.skolverket.se

Merey, S. (2012). Children Rights in Social Studies Curricula in Elementary Education: A Comparative Study. Educational Sciences: Theory \& Practice, 3273-3284. http://www.edam.com.tr/estp

Miranda, L. A. (2013). Introduction to Indigenous People’s Status and Rights under International Human Rights Law. In R. S. Abate, \& E. A. Kronk (Eds.), Climate Change and Indigenous Peoples. The Search for Legal Remedies. Cheltenham: Edward Elgar Publishing Limited.

Omma, L. (2013). Ung same i Sverige—Livsvillkor, självvärdering och hälsa. Ph.D. Thesis, Umeå: Umeå Universtiy.

Parliamentary Resolution 1962 Regarding the Nomadic School (Prop. 1962:51 till Riksdagen ang. Nomadskolväsendets organisation, s.18; Statsutskottets utlåtande ang. Nomaskolväsendets organisation 1962:141 s.2, 10f; Protokoll ang. Nomadskolväsendets organisation FK:25 s.5ff; Protokoll AK:24 s.191ff).

Pikkarainen, H., \& Brodin, B. (2008). Discrimination of National Minorities in the Education System. DO’s Report No. 2008:2, Stockholm: Ombudsmannen mot etnisk diskriminering. http://www.do.se

Porsanger, J. (2010). Self-Determination and Indigenous Research: Capacity Building on Our Own Terms. Towards an Alternative Development Paradigm: Indigenous People’s Self Determination Development. Baguio City: Tebtebba Foundation.

Prop. 1989/90:107. Regeringens proposition om godkännande av FN-konventionen om barns rättigheter.

Rahman, K. (2013). Belonging and Learning to Belong in School: The Implications of the Hidden Curriculum for Indigenous Students. Discourse: Studies in the Cultural Politics of Education, 34, 660-672.

http://dx.doi.org/10.1080/01596306.2013.728362

Rasheed, A. A. (2014). Inclusive Education in Nigeria-A Myth or Reality? Creative Education, 5, 1777-1781. http://dx.doi.org/10.4236/ce.2014.520198

Regeringsformen i Grundlagen (The Constitutions of Sweden).

Rico, B. (2013). Awakening Vision: Examining the Reconceptualization of Aboriginal Education in Canada via Kaupapa Māori praxis. Asia Pacific Journal of Education, 33, 380-393. http://dx.doi.org/10.1080/02188791.2013.807775

Sameskolstyrelesen. (Sámi school board). http://www.sameskolstyrelsen.se

SFS 1938:479 Kungl. Maj:ts stadga angående nomadundervisningen.

SFS 2009:600 Språklagen (Language Act). http://www.riksdagen.se

SFS 2009:724, Lag om nationella minoriteter och minoritetsspråk (The Act on National Minorities and Minority Language). http://www.riksdagen.se

SFS 2010:800 Skollagen (Educational Act). http://www.riksdagen.se

Smith, L. T. (2012). Decolonizing Methodologies. Research and Indigenous Peoples (2nd ed.). London \& New York: Zed Books.

SÖ 2002:2 Sveriges internationella Överenskommelser, Ramkonvention om skydd för nationella minoriteter.

Tallberg, B. I., Rubenstein, R. L., \& Hägerström, J. (2002). Likvärdighet i en skola för alla—Historisk bakgrund och kritisk granskning. Stockholm: Statens skolverk.

Utsi, P. M. (2007). Traditionell kunskap och sedvänjor inom den samiska kulturen—Relaterat till bevarande och hållbart nyttjande av biologisk mångfald. CBM:s skriftserie 18. Sametinget, Kiruna och Centrum för biologisk mångfald. Uppsala. http://www.cbm.slu.se/publ/skrift18.pdf 